\title{
Pengaruh Pembelajaran Kooperatif Tipe Jigsaw Kontekstual Terhadap Kemampuan Koneksi Matematik Ditinjau Dari Disposisi Matematik Siswa SMA
}

\author{
(Effect Of Contextual Jigsaw Type Of Cooperative Learning Model On Mathematic
}

Connection Ability Viewed From Mathematic Disposition Of Senior High School Students)

\author{
Kamaruddin $^{1}$, Kadir $^{2}$, Ruslan $^{3}$ \\ ${ }^{1}$ Guru SMA Negeri 1 Wakorumba Utara, Alumnus Prodi Pendidikan Matematika PPs Universitas Halu Oleo \\ ${ }^{2}$ Dosen Pendidikan Matematika FKIP dan PPS Universitas Halu Oleo \\ ${ }^{3}$ Dosen MIPA dan PPs Universitas Halu Oleo; Co-author: rushlan_a@yahoo.com
}

\begin{abstract}
Abstrak: Penelitian ini merupakan penelitian RAK dengan tujuan untuk menganalisis: (1) Deskripsi kemampuan koneksi matematik (KON) ditinjau dari disposisi matematik (DM) siswa kelas X SMA Negeri 1 Wakorumba Utara; (2) Perbedaan rata-rata peningkatan kemampuan koneksi matematik antara siswa yang diajar dengan pembelajaran kooperatif tipe jigsaw kontekstual dan pembelajaran langsung kontekstual; (3) Perbedaan rata-rata peningkatan kemampuan koneksi matematik siswa yang diajar dengan pembelajaran kooperatif tipe jigsaw kontekstual dan pembelajaran langsung kontekstual ditinjau dari disposisi matematik siswa. Populasi dalam penelitian ini adalah seluruh siswa kelas X di SMA Negeri 1 Wakorumba Utara tahun ajaran 2016/2017 dengan jumlah siswa 97 orang. Hasil penelitian secara deskriptif dan inferensial menunjukkan bahwa: (1) Kemampuan KON siswa kelas X SMA Negeri 1 Wakorumba Utara meningkat setelah diberikan atau menggunakan masalah kontekstual, (2) Melalui independent sample t-test secara signifikan rata-rata peningkatan kemampuan koneksi matematik siswa yang diajar dengan pembelajaran kooperatif tipe jigsaw kontekstual lebih besar di banding dengan pembelajaran langsung kontekstual; (3) Melalui anava RAK disimpulkan bahwa ada perbedaan yang signifikan rata-rata peningkatan KON siswa antara yang diajar dengan pembelajaran kooperatif tipe jigsaw kontekstual dan yang diajar dengan pembelajaran langsung kontekstual ditinjau dari DM siswa.
\end{abstract}

Kata kunci: Kemampuan koneksi matematik, disposisi matematik, pembelajaran kooperatif tipe Jigsaw kontekstual

\begin{abstract}
This study was a RAK research which aimed to analyze: (1) a description of mathematics connection ability (KON) viewed from mathematic disposition (DM) of class $\mathrm{X}$ students at SMA Negeri 1 of North Wakorumba; (2) the difference in the average increase of mathematics connection ability between students who were taught using contextual jigsaw type of cooperative learning model and direct contextual learning; (3) the difference in the average increase of mathematics connection ability between students who were taught using contextual jigsaw type of cooperative learning model and direct contextual learningviewed from their mathematic disposition. Population of the study included all students of class X at SMA Negeri 1 of North Wakorumba in 2016/2017 academic years, totaling 97 students. Results of the study, descriptively and inferentially, showed that: (1) the increases of students' KON at class X of SMA Negeri 1 of North Wakorumba was still categorized as moderate, both before and after treatment, (2) result of independent sample t-test showed that the average increase in the students' mathematics connection ability gained by those who were taught using the contextual jigsaw type of cooperative learning model was significantly higher than that achieved by their cohorts who received contextual direct learning, (3) Anava RAK led to the conclusion that there was a significant difference in the average increase of mathematics connection ability between the students who were taught using the jigsaw type of cooperative learning model and those who received contextual direct learning viewed from the students' DM.
\end{abstract}

Keywords: Mathematics Connection Ability, Mathematics Disposition, Contextual Jigsaw Type Of Cooperative Learning Model

\section{PENDAHULUAN}

Matematika merupakan salah satu bidang ilmu dasar yang memiliki peranan

penting dalam pengembangan ilmu pengetahuan dan teknologi. Matematika 
merupakan suatu alat untuk mengembangkan cara berpikir. Karena itu, pembelajaran matematika sangat diperlukan baik untuk kehidupan seharihari maupun dalam menghadapi kemajuan IPTEK (Ilmu Pengetahuan dan Teknologi), sehingga matematika perlu dibekalkan kepada setiap peserta didik sejak SD (Sekolah Dasar), bahkan sejak TK (Taman Kanak-Kanak). Perlunya mata pelajaran matematika diberikan kepada semua siswa mulai dari sekolah TK yang tujuannya adalah untuk membekali siswa dengan kemampuan berpikir logis, analitis, sistematis, kritis, dan kreatif, serta kemampuan bekerjasama. Hal ini diperlukan agar siswa dapat memiliki kemampuan memperoleh, mengelola dan memanfaatkan informasi untuk bertahan hidup pada keadaan yang selalu berubahubah dan kompetitif. Penguasaan matematika sejak dini merupakan hal yang sangat penting.

National Council of Teachers of Mathematics (NCTM) (2000: 29) merumuskan tujuan pembelajaran matematika yang disebut mathematical power (daya matematik) meliputi: 1) belajar untuk berkomunikasi (mathematical communication), 2) belajar untuk bernalar (mathematical reasoning), 3) belajar untuk memecahkan masalah (mathematical problem solving), 4) belajar untuk mengaitkan ide (mathematical connection), dan 5) belajar untuk merepresentatif (representation). Soedjadi (2000: 43) mengemukakan tujuan pembelajaran matematika, yaitu: 1) mempersiapkan siswa agar sanggup menghadapi perubahan keadaan dan pola pikir dalam kehidupan dan dunia yang selalu berkembang, dan 2) mempersiapkan siswa menggunakan matematika dan pola pikir matematika dalam kehidupan seharihari dan dalam mempelajari berbagai ilmu pengetahuan. Dari pendapat di atas, kemampuan siswa membuat koneksi merupakan salah satu dari tujuan dalam pembelajaran matematika. Oleh karena itu, dalam pembelajaran matematika siswa perlu mempunyai kemampuan koneksi matematik.

Kemampuan koneksi merupakan aspek yang sangat penting dalam pembelajaran matematika. Koneksi (connections) merupakan standar proses yang termuat dalam NCTM (2000: 7). Kemampuan koneksi matematik siswa yang rendah akan mempengaruhi kualitas belajar siswa yang akan berdampak pada rendahnya hasil belajar matematika siswa. Siswa dengan kemampuan koneksi yang rendah akan selalu mengalami kesulitan menghadapi dan menyelesaikan permasalahan. Kemampuan koneksi siswa harus diasah agar siswa dapat menggunakan suatu konsep untuk dihubungkan dengan konsep lainnya. Apabila siswa diperkenalkan dengan koneksi, maka siswa diharapkan dapat meningkatkan hasil belajarnya.

Salah satu bagian yang integral dari pembelajaran matematika adalah menulis, yakni untuk memperoleh, mengelola dan memanfaatkan informasi. Dengan tulisan seseorang dapat menyampaikan hasil pemikirannya kepada orang lain, orang lainpun mengetahui apa yang sedang dikerjakan. Pemahaman erat kaitannya dengan kemampuan koneksi matematik (mathematical connection). Hal ini didasarkan pada kenyataan bahwa dengan meningkatnya kemampuan siswa untuk menghubungkan antar konsep dan ide-ide matematika, maka kemampuan pemahaman siswa tersebut akan ikut bertambah.

Membangun koneksi matematik menurut Jihad (2008: 169), dapat memberikan tujuan pada siswa untuk: 1) mencari hubungan berbagai representasi konsep dan prosedur, 2) memahami hubungan antar topik matematika, 3) menggunakan matematika dalam bidang studi lain atau kehidupan sehari-hari, 4) memahami representasi ekuivalen konsep yang sama, 5) mencari koneksi satu prosedur ke prosedur lain dalam 
representasi yang ekuivalen, dan 6) menggunakan koneksi antar topik matematika, dan antara topik matematika dengan topik lain.

Tujuan yang ideal tersebut pada kenyataannya tidak selalu mudah dicapai oleh sekolah. Sebagai gambaran berdasarkan pengalaman peneliti sebagai guru matematika kelas X SMA ( Sekolah Menengah Atas ) Negeri 1 Wakorumba Utara di Kabupaten Buton Utara, diperoleh informasi bahwa memang proses pembelajaran di kelas X SMA Negeri 1 Wakorumba Utara sudah cukup optimal, tetapi siswa masih kesulitan dalam menyelesaikan soal terkait menuliskan masalah kehidupan sehari-hari ke dalam bentuk model matematika. Siswa juga masih kesulitan dalam menghubungkan antar obyek dan konsep dalam matematika. Selain itu, siswa juga masih kesulitan dalam menentukan rumus apa yang akan dipakai jika dihadapkan pada soal-soal yang berkaitan dengan masalah kehidupan sehari-hari. Fakta ini menunjukkan rendahnya kemampuan koneksi matematik siswa.

Siswa tidak memiliki kemampuan menganalisis dan memecahkan masalah dengan berbagai cara, siswa tidak mampu menghubungkan ide-idenya dari satu konsep ke konsep lainnya. Ketika peneliti melakukan observasi awal pada pembelajaran matematika di kelas, guru kurang melibatkan siswa secara optimal, sehingga siswa kurang aktif dalam belajar. Sebagian besar siswa tampak mengikuti dengan baik setiap penjelasan atau informasi dari guru, siswa hampir tidak pernah mengajukan pertanyaan pada guru sehingga guru asyik sendiri menjelaskan apa yang telah disiapkannya. Siswa hanya menerima saja apa yang disampaikan oleh guru. Pada kondisi seperti ini, kesempatan siswa untuk menemukan dan membangun pengetahuannya sendiri hampir tidak ada. Hal ini berakibat juga dengan rendahnya keinginan, kesadaran, dan dedikasi yang kuat pada diri siswa untuk belajar matematika dan melaksanakan berbagai kegiatan matematika.

Berdasarkan hal di atas, peneliti melakukan observasi dan wawancara kepada siswa kelas X SMA Negeri 1 Wakorumba Utara terhadap masalah yang telah dikemukakan oleh guru. Peneliti melihat bahwa siswa kesulitan dalam menghubungkan antar konsep yang sebelumnya telah diketahui oleh siswa dengan konsep baru yang akan siswa pelajari. Misalnya, Siswa kesulitan menghubungkan konsep perbandingan trigonometri dan dalil phytagoras untuk menentukan besar salah satu sudut pada suatu segitiga siku-siku yang panjang kedua sisinya diketahui. Kesulitan siswa tersebut dapat di kategorikan dalam kesulitan melakukan koneksi matematik. Hasil wawancara dan hasil observasi tersebut menunjukkan adanya kemampuan koneksi matematik siswa kelas X SMA Negeri 1 Wakorumba Utara yang masih belum optimal.

Perubahan paradigma pembelajaran dari pandangan mengajar yang berpusat pada guru ke pandangan pembelajaran yang berpusat pada siswa. Pembelajaran kooperatif tipe jigsaw kontekstual merupakan pembelajaran yang didalamnya siswa mengkonstruksi pemikirannya sendiri untuk berperan aktif dalam pembelajaran dan dalam menyelesaikan masalah matematika yang berkaitan dengan konteks kehidupan nyata. Siswa didorong untuk mengkontruksi pengetahuan yang dimilikinya dengan penerapannya dalam kehidupan mereka sehari-hari. Pembelajaran kooperatif tipe jigsaw kontekstual juga merupakan salah satu model pembelajaran inovatif yang dapat memberikan kondisi belajar aktif dan menyenangkan kepada siswa. Pembelajaran kooperatif tipe jigsaw kontekstual adalah suatu pembelajaran yang memberikan penekanan kepada siswa pada penggunaan berpikir tingkat tinggi, transfer pengetahuan, pemodelan, informasi dan data dari sumber lainnya. 
Guru perlu merancang suatu pembelajaran yang membiasakan siswa untuk mengkonstruksi sendiri pengetahuannya dan yang dapat mendukung serta mengarahkan siswa pada kemampuan untuk berkomunikasi matematik dalam memecahkan masalah matematika.

Penggunaan pembelajaran kooperatif tipe jigsaw kontekstual dalam pembelajaran matematika, proses pembelajaran akan lebih bermakna, karena dapat meluruskan konsep matematika

\section{METODE PENELITIAN}

Jenis penelitian ini adalah penelitian quasi eksperimen dan dilaksanakan di SMA Negeri 1 Wakorumba Utara Kabupaten Buton Utara, dengan populasi dalam penelitian ini adalah seluruh siswa kelas X SMA Negeri 1 Wakorumba Utara tahun ajaran 2016/2017 yang tersebar dalam empat kelas paralel yakni kelas X-1 sampai kelas X-4 dengan jumlah siswa 97 orang. Untuk menentukan kelas yang akan dijadikan penelitian menggunakan purposive sampling dan random class. yang sifatnya abstrak ke dalam konteks kehidupan nyata atas masalah-masalah yang diberikan. Pembelajaran yang seperti ini akan menumbuhkembangkan sikap kritis, cermat, objektif, terbuka, menghargai keindahan matematika, rasa ingin tahu, dan senang belajar matematika yang merupakan bagian-bagian dari disposisi matematik. Sehingga siswa akan merasa nyaman berada di kelas serta aktif dalam kegiatan pembelajaran di kelas.

Teknik purposive sampling yaitu mengambil dua kelas dari kelas paralel yang homogen berdasarkan uji perbedaan rataan dan uji homogenitas varians. Pemilihan kelas eksperimen dan kelas kontrol digunakan random class pada empat kelas tersebut diperoleh kelas X-3 (24 siswa) sebagai kelas eksperimen dan kelas X-1 (24 siswa) sebagai kelas kontrol. Menurut Sukardi (2003: 55), jika keadaan populasi homogen atau mempunyai karakteristik sama maka jumlah sampel dapat lebih kecil.

Tabel 1. Gambaran Pengambilan Jumlah Sampel dalam Penelitian Eksperimen

\begin{tabular}{cccc} 
B & & $\mathbf{A}$ & \multicolumn{1}{c}{ Jumlah } \\
\hline $\mathrm{B}_{1}$ & $\mathbf{A}_{\mathbf{1}}$ & $\mathbf{A}_{\mathbf{2}}$ & 16 \\
$\mathrm{~B}_{2}$ & 8 & 10 & 17 \\
$\mathrm{~B}_{3}$ & 10 & 9 & 15 \\
Jumlah & 24 & 5 & 48 \\
\hline
\end{tabular}

Dimana $\mathrm{A}_{1}$ adalah model pembelajaran kooperatif tipe jigsaw kontekstual dan $\mathrm{A}_{2}$ adalah pembelajaran langsung kontekstual, dan B adalah disposisi matematik dengan kategori tinggi $\left(\mathrm{B}_{1}\right)$, sedang $\left(\mathrm{B}_{2}\right)$ dan $\left(\mathrm{B}_{3}\right)$ rendah. Variabel dalam penelitian ini terdiri atas variabel dependen (variabel terikat) yaitu kemampuan koneksi matematik siswa dan variabel independen (variabel bebas) yaitu model pembelajaran sebagai faktor A dan disposisi matematik sebagai faktor B. Faktor A terdiri dari $A_{1}$ model PTJK sebagai kelompok eksperimen 1 dan $\mathrm{A}_{2}$ model PLK sebagai kelompok eksperimen 2. Sedangkan faktor $B$ terdiri atas $D M$ tinggi $\left(B_{1}\right)$, DM sedang $\left(B_{2}\right)$ dan $D M$ rendah $\left(\mathrm{B}_{3}\right)$. Variabel terikat dalam penelitian menggunakan instrumen yang divalidasi melalui panelis (tim ahli) dengan menggunakan Randomized Control Group Design sebagaimana dijelaskan pada desain berikut: 


$\begin{array}{cccc}\mathrm{E} & \mathrm{T}_{01} & \mathrm{X} & \mathrm{T}_{11} \\ \mathrm{~K} & \mathrm{~T}_{02} & - & \mathrm{T}_{12}\end{array}$

di mana:

E : Kelas Eksperimen.

K : Kelas Kontrol.

$\mathrm{X}$ : Perlakuan, yaitu model pembelajaran kooperatif tipe jigsaw kontekstual dan langsung kontekstual

$\mathrm{T}_{01}, \mathrm{~T}_{02}$ : Pretest siswa kelas eksperimen dan kontrol sebelum pembelajaran

$\mathrm{T}_{11}, \mathrm{~T}_{12}$ : Posttest siswa kelas eksperimen dan kontrol setelah pembelajaran.

Teknik yang digunakan dalam pengambilan data adalah teknik tes kemampuan koneksi matematik dan angket disposisi matematik. Adapun tahapan dalam mengumpulkan data tersebut yakni (1) Menyusun instrumen penelitian (silabus, rencana pelaksanaan pembelajaran, lembar kerja siswa, kisi-kisi soal pretest dan posttest untuk mengukur kemampuan koneksi matematik siswa dan kisi-kisi item angket untuk mengukur disposisi matematik siswa, serta rubrik penskoran); (2) Meminta beberapa dosen ahli untuk memvalidasi instrumen penelitian (pretest dan posttest kemampuan koneksi matematik); (3) Melakukan uji coba instrumen penelitian (disposisi matematik); (4) Estimasi validitas dan reliabilitas instrumen penelitian; (5) Revisi instrumen penelitian; (6) Memberikan pretest kemapuan koneksi matematik dan angket disposisi matematik kepada sampel penelitian; (7) Melaksanakan penelitian di sekolah; dan (8) Memberikan posttest kemapuan koneksi matematik kepada sampel penelitian.

Analisis data yaitu proses mengatur urutan data, mengorganisasikannya ke dalam suatu pola, kategori, dan satuan uraian dasar. Analisa data adalah rangkaian kegiatan penelaahan, pengelompokkan, sistematisasi, penafsiran, dan verifikasi data agar sebuah fenomena memiliki nilai sosial, akademis, dan ilmiah. Kegiatan analisis data diawali dengan ujian prasyarat yaitu analisis validitas dan reliabilitas instrumen penelitian.

Analisis deskriptif dimaksudkan untuk mendeskripsikan karakteristik responden melalui skor rata-rata dan standar deviasi dari masing-masing sel yang dibentuk oleh model pembelajaran kooperatif tipe jigsaw kontekstual dan langsung kontekstual serta disposisi matematik. Analisis deskriptif tersebut mencakup mean (rata-rata) dan standar deviasi.

Analisis inferensial merupakan analisis yang digunakan untuk menguji sejumlah hipotesis penelitian, sebelumnya melalui uji normalitas dan homogenitas. Uji Normalitas menggunakan statistik uji Kolmogorov-Smirnov dan uji homogenitas menggunakan statistik uji Levene. Uji normalitas data dimaksudkan untuk mengetahui apakah data yang diperoleh berasal dari populasi yang berdistribusi normal atau tidak berdistribusi normal. Untuk keperluan ini digunakan statistik uji Kolmogorov-Smirnov. Dengan hipotesis sebagai berikut:

$\mathrm{H}_{0}$ : Sampel berasal dari populasi yang berdistribusi normal

$\mathrm{H}_{1}$ : Sampel berasal dari populasi yang tidak berdistribusi normal

Uji homogenitas variansi populasi dimaksudkan untuk mengetahui apakah varian dari kedua sampel yang diselidiki homogen atau tidak homogen. Uji homogenitas menggunakan perangkat program analisis siap pakai yaitu SPSS, berdasarkan uji Levene yaitu statistik uji F. Pada uji Levene tidak harus berdistribusi normal, namun harus kontinyu. Pengujian hipotesis yaitu :

$$
\begin{gathered}
\mathrm{H}_{0}: \begin{array}{c}
\sigma_{1}{ }^{2}=\sigma_{2}{ }^{2}=\cdots=\sigma_{k}{ }^{2} \quad \text { (data } \\
\text { homogen) }
\end{array} \\
\mathrm{H}_{1}: \begin{array}{c}
\text { paling sedikit ada } \\
\text { tidak sama }
\end{array}
\end{gathered}
$$

Jika $\mathrm{F}_{\text {hit }} \leq \mathrm{F}_{\text {tab }}$ maka $\mathrm{H}_{0}$ diterima, yang berarti kedua kelas mempunyai varians 
homogen, dan jika $\mathrm{F}_{\text {hit }}>\mathrm{F}_{\text {tab }}$ maka $\mathrm{H}_{0}$ ditolak, yang berarti kedua kelas mempunyai varians tidak homogen. Pengujian dilakukan pada taraf signifikan

\section{HASIL PENELITIAN}

Deskripsi perbandingan rata-rata dan standar deviasi $n$-gain KON kedua kelas, yaitu kelas yang diajar dengan PKTJK dan $\alpha=0,05$ dan derajat kebebasan pada $\mathrm{dk}=$ $\left(\alpha ; \mathrm{n}_{1}-1 ; \mathrm{n}_{2}-1\right)$.

kelas yang diajar dengan PLK. Grafiknya sebagai berikut.

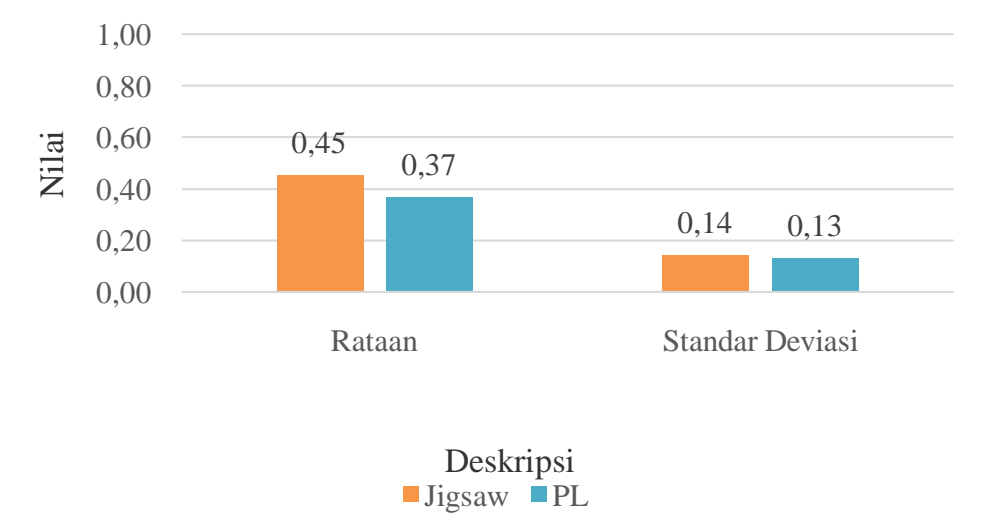

\section{Gambar 1. Perbandingan Rataan dan Standar Deviasi $\mathbf{N}$-Gain KON Siswa}

Berdasarkan Gambar 1 diperoleh bahwa peningkatan KON siswa pada kelas yang diajar dengan PKTJK lebih tinggi dibandingkan dengan kelas yang diajar dengan PLK. Namun demikian, pernyataan ini masih perlu diuji secara statistik inferensial.

Hasil analisis deskriptif terhadap nilai KON siswa dari kedua kelas berdasarkan pengelompokan kategori DM siswa disajikan pada Tabel 2.

Tabel 2. Deskripsi Nilai KON Siswa berdasarkan Kategori DM

\begin{tabular}{cccccccc}
\hline \multirow{2}{*}{$\begin{array}{c}\text { Kategori } \\
\text { DM }\end{array}$} & Stats & \multicolumn{6}{c}{ Pembelajaran Menggunakan } \\
& & Pre & Post & N-Gain & Pre & Post & N-Gain \\
\hline \multirow{2}{*}{ DM } & n & 6 & 6 & 6 & 10 & 10 & 10 \\
Tinggi & Rataan & 4.8333 & 7 & 0.51 & 4.2 & 6 & 0.36 \\
& St. Dev & 0.7528 & 0.6325 & 0.14773 & 1.033 & 0.667 & 0.13404 \\
DM & n & 8 & 8 & 8 & 9 & 9 & 9 \\
Sedang & Rataan & 4.63 & 6.75 & 0.52 & 4.33 & 6.22 & 0.40 \\
& St. Dev & 1.30 & 1.16 & 0.14 & 0.87 & 0.83 & 0.14 \\
DM & n & 10 & 10 & 10 & 5 & 5 & 5 \\
Rendah & Rataan & 4.50 & 6.20 & 0.37 & 4.20 & 5.80 & 0.32 \\
& St. Dev & 1.08 & 0.63 & 0.11 & 1.10 & 0.45 & 0.11 \\
\hline
\end{tabular}

Tabel 2 memberikan gambaran bahwa kualitas KON siswa berdasarkan DM pada dua kelas yang berbeda. Pada
Tabel 2 juga secara deskriptif memberikan informasi bahwa pada kategori DM tinggi rataan $N$-Gain KON siswa kelas yang 
diajar PKTJK sebesar 0.51 dengan standar deviasi sebesar 0.14 dan rataan $N$-Gain KON siswa kelas yang diajar PLK sebesar 0.36 dengan standar deviasi sebesar 0.13. Pada kategori DM sedang rataan $N$-Gain KON siswa kelas yang diajar PKTJK sebesar 0.52 dengan standar deviasi sebesar 0.14 dan rataan $N$-Gain $\mathrm{KON}$ siswa kelas yang diajar PLK sebesar 0.40 dengan standar deviasi sebesar 0.14. Pada kategori DM rendah rataan $N$-Gain $\mathrm{KON}$ siswa kelas yang diajar PKTJK sebesar 0.37 dengan standar deviasi sebesar 0.11 dan rataan $\mathrm{N}$-Gain $\mathrm{KON}$ siswa kelas yang mengikuti PLK sebesar 0.32 dengan standar deviasi sebesar 0.11. Untuk lebih jelasnya dapat dilihat pada Gambar 2.

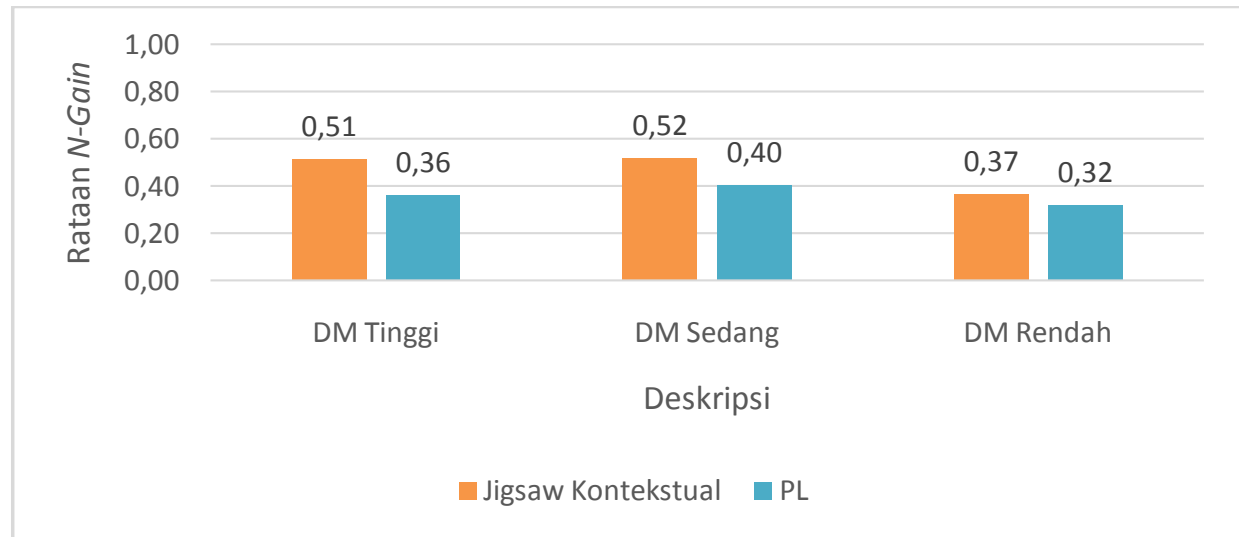

Gambar 2. Perbandingan Rataan N-Gain KON sesuai Kategori DM

Berdasarkan interpretasi nilai $N$ Gain, rata-rata peningkatan KON siswa pada kelompok DM tinggi, DM sedang, dan DM rendah yang diajar dengan PKTJK dan PLK termasuk dalam kategori sedang.

Berdasarkan uraian di atas dapat disimpulkan bahwa ada keterkaitan antara pembelajaran PKTJK dan PLK terhadap KON siswa. Penerapan PKTJK dan PLK secara signifikan telah dapat meningkatkan KON siswa baik ditinjau dari kategori DM siswa. Dari kedua bentuk perlakuan tersebut, PKTJK lebih berpengaruh dibandingkan dengan PLK terhadap KON siswa.

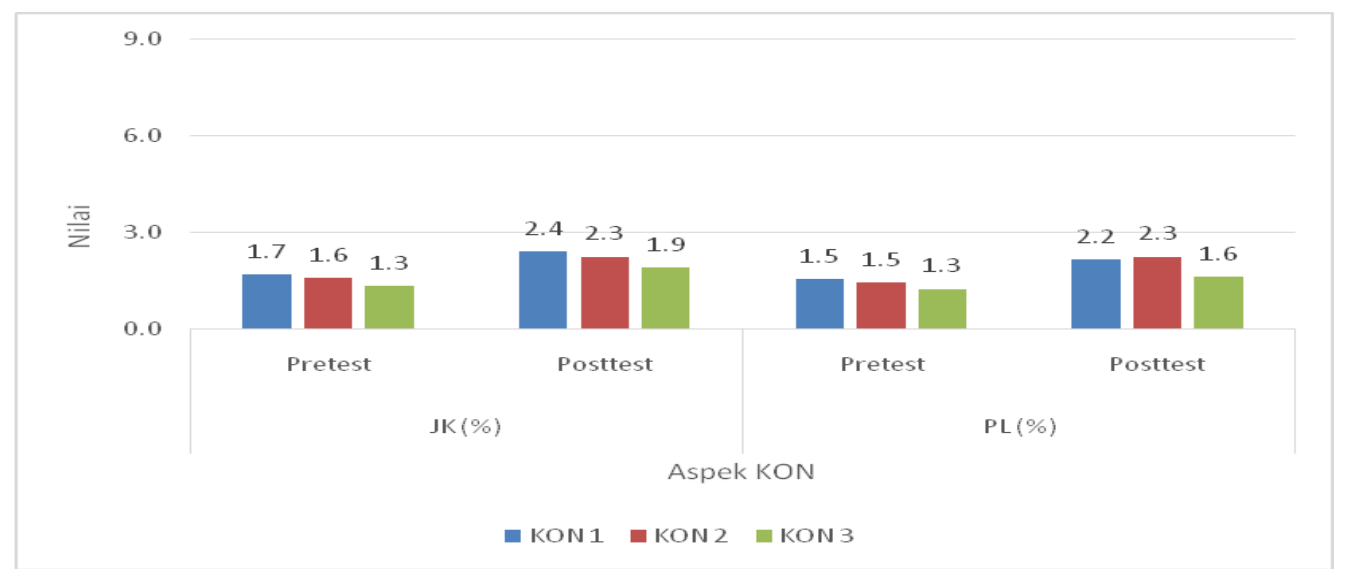

Gambar 3. KON Siswa Per-Aspek pada Masing-Masing Indikator

Selanjutnya, berdasarkan tiga aspek
KON yang dikembangkan dalam


penguasaan siswa terhadap kemampuan tersebut. Aspek KON 1, 2, dan 3 secara keseluruhan terjadi peningkatan pada setiap indikatornya. Siswa mampu menghubungkan antar topik matematika, matematika dengan bidang ilmu lain dan menghubungkan matematika dengan kehidupan sehari-hari. Hasil pekerjaan siswa terhadap tiga butir soal (tes KON) yang diberikan menunjukkan bahwa siswa yang diajar dengan PKTJK dan PLK, ratarata KON setiap aspeknya mengalami peningkatan.

Keterangan:

KON 1 : Menghubungkan antar topik matematika.

KON 2 : Menghubungkan matematika dalam bidang ilmu lain.

KON 3 : Menghubungkan matematika dalam kehidupan sehari-hari.

Berdasarkan uji $\mathrm{t}$ diperoleh bahwa bahwa Nilai $\mathrm{t}=13.899$ dengan Sig. $=$ $0.000 / 2=0.000$, Karena nilai Sig. $<\alpha=$ 0.05 , maka $\mathrm{H}_{0}$ ditolak. Dengan ditolaknya $\mathrm{H}_{0}$ maka dapat disimpulkan bahwa secara signifikan terdapat peningkatan kemampuan KON siswa yang diajar dengan model PKTJK.

Berdasarkan uji $\mathrm{t}$ diperoleh bahwa Nilai $\mathrm{t}=10.537$ dengan Sig.= $0.000 / 2=0.000$, Karena nilai Sig. $<\alpha=$ 0.05 , maka $\mathrm{H}_{0}$ ditolak. Dengan ditolaknya $\mathrm{H}_{0}$ maka dapat disimpulkan bahwa secara signifikan terdapat peningkatan kemampuan KON siswa yang diajar dengan model PLK.

Berdasarkan uji $\mathrm{t}$ diperoleh bahwa Nilai $\mathrm{t}=2,167$ dengan Sig. $=$ $0.035 / 2=0.0175$, Karena nilai Sig. $<\alpha=$ 0.05 , maka $\mathrm{H}_{0}$ ditolak. Dengan ditolaknya $\mathrm{H}_{0}$ maka dapat disimpulkan bahwa secara signifikan peningkatan kemampuan KON matematik siswa antara siswa yang diajar dengan PKJTK lebih tinggi daripada

\section{PEMBAHASAN}

Hasil analisis data baik dari analisis deskriptif maupun analisis inferensial menunjukan bahwa ada perbedaan KON peningkatan kemampuan $\mathrm{KON}$ matematik siswa yang diajar dengan model PLK.

Berdasarkan uji RAK ANAVA diperoleh bahwa pada baris kelas nilai $\mathrm{F}=$ 6,898 dengan Sig. $=0.012$. Karena nilai Sig. $<\alpha=0.05$, maka $\mathrm{H}_{0}$ ditolak. Dengan ditolaknya $\mathrm{H}_{0}$ maka dapat disimpulkan bahwa secara signifikan ada perbedaan rata-rata peningkatan kemampuan $\mathrm{KON}$ matematik siswa antara siswa yang diajar dengan PKTJK dan PLK ditinjau dari DM.

Berdasarkan uji t diperoleh bahwa Nilai $\mathrm{t}=2.537$ dengan Sig.= $0.022 / 2=0.011$, Karena nilai Sig. $<\alpha=$ 0.05 , maka $\mathrm{H}_{0}$ ditolak. Dengan ditolaknya $\mathrm{H}_{0}$ maka dapat disimpulkan bahwa secara signifikan peningkatan kemampuan KON matematik siswa yang diajar dengan PKTJK lebih tinggi daripada peningkatan kemampuan KON matematik siswa yang diajar dengan PLK ditinjau dari siswa yang memiliki DM tinggi.

Berdasarkan uji t diperoleh bahwa Nilai $\mathrm{t}=0,994$ dengan Sig. $=$ $0.338 / 2=0.169$, Karena nilai Sig. $>\alpha=$ 0.05, maka $\mathrm{H}_{0}$ diterima. Dengan diterimanya $\mathrm{H}_{0}$ maka dapat disimpulkan bahwa secara signifikan tidak ada perbedaan rata-rata peningkatan kemampuan KON matematik siswa yang diajar dengan PKTJK dan PLK pada siswa dengan DM sedang.

Berdasarkan uji t diperoleh bahwa Nilai $\mathrm{t}=0,822$ dcengan Sig. $=$ $0.426 / 2=0.213$, Karena nilai Sig. $>\alpha=$ 0.05 , maka $\mathrm{H}_{0}$ diterima. Dengan diterimanya $\mathrm{H}_{0}$ maka dapat disimpulkan bahwa Secara signifikan tidak tidak ada perbedaan rata-rata kemampuan koneksi matematik siswa yang diajar dengan PKTJK dan PLK pada siswa dengan DM rendah.

siswa pada masing-masing kelas yang yang diajar dengan PKTJK dan PLK. Tetapi setelah membandingkan pada 
masing-masing kelas melalui uji statistik dan deskriptif, maka terdapat perbedaan yang signifikan KON siswa antara kelompok siswa yang diajar menggunakan PKTJK dan dengan kelompok siswa yang diajar menggunakan PLK. Hal ini terlihat pada nilai rata-rata $\mathrm{N}$-Gain kedua kelompok yang menyimpulkan bahwa nilai rata-rata $\mathrm{N}$-Gain $\mathrm{KON}$ siswa yang diajar menggunakan PKTJK lebih tinggi dari pada nilai rata-rata $\mathrm{N}$-Gain kelompok siswa yang diajar menggunakan PLK.

Dari hasil uji hipotesis yang telah dikemukakan sebelumnya ditemukan bahwa terdapat perbedaan KON siswa yang diajar dengan PKTJK dan siswa yang diajar dengan PLK. Artinya, perbedaan KON itu ada, karena perbedaan perlakuan pembelajaran yang diberikan pada masing-masing kelas menunjukan bahwa PKTJK lebih baik dalam hal meningkatkan KON siswa dibandingkan denganPLK. Hal ini juga sejalan dengan yang dikemukakan oleh Anghileri (2006: 33), bahwa proses perolehan keterampilan seorang anak adalah aktivitas dimana keterampilan yang relevan dikombinasikan agar menjadi keterampilan yang lebih tinggi sebagai syarat menyelesaikan tugas baru yang lebih kompleks dan akan berhasil apabila ada intervensi orang lain sebagai tutor. Tetapi dengan dikaitkan dengan masalah yang kontekstual dengan kehidupan nyata siswa, akan menambah peningkatan aktivitas siswa ketika sedang belajar kelompok. Pembelajaran akan lebih bermakna karena pembelajaran dikaitkan dengan masalah kehidupan sehari-hari siswa. Pengaruh disposisi matematik terhadap KON siswa begitu berarti setelah perlakuan diberikan. Terlihat bahwa siswa yang diajar dengan PKTJK memperoleh nilai N-Gain lebih tinggi dari siswa yang mengikuti PLK ditinjau dari dispososi matematik. Sehingga dapat disimpulkan bahwa pengaruh PKTJK dan DM mempunayai pengaruh yang sangat dominan terhadap kemampuan KON siswa.

Hasil penelitian juga menyimpulkan bahwa secara umum terdapat perbedaan yang signifikan peningkatan kemapuan KON siswa antara kelas yang diajar dengan PKTJK dan kelas yang diajar dengan PLK ditinjau dari DM. Pada kelompok siswa dengan kategori DM tinggi yang diajar dengan PKTJK memperoleh rataan $\mathrm{N}$-Gain $\mathrm{KON}$ sebesar 0.51 lebih tinggi dibandingkan dengan rataan KON siswa yang diajar PLK yaitu sebesar 0.36. Pada kelompok siswa dengan DM sedang yang diajar dengan PKTJK memperoleh rataan $\mathrm{N}$-Gain KON sebesar 0.52 lebih tinggi dibandingkan dengan rataan $\mathrm{N}$-Gain KON siswa yang diajar dengan PLK yaitu sebesar 0.40 . Pada kelompok siswa dengan DM rendah yang diajar dengan PKTJK memperoleh rataan $\mathrm{N}$-Gain $\mathrm{KON}$ sebesar 0.37 lebih tinggi dibandingkan dengan rataan N-Gain KON siswa yang diajar dengan PLK yaitu sebesar 0.32. Berdasarkan uraian tersebut, dapat disimpulkan bahwa terdapat pengaruh PKTJK terhadap KON siswa ditinjau dari DM, yaitu kategori DM tinggi, sedang dan rendah.

Faktor model pembelajaran yang digunakan guru berpengaruh signifikan terhadap KON siswa ditinjau dari kategori DM serta aktivitas siswa selama mengikuti proses pembelajaran. Pada PLK, guru merupakan sentral dari kegiatan proses pembelajaran dan membuat siswa berperan pasif. Akibatnya siswa menjadi kurang tertarik terhadap materi yang diajarkan, tidak menumbuh kembangkan rasa keingin tahuan siswa terhadap materi yang dipelajari, siswa merasa bosan dan berharap proses pembelajaran segera berakhir sehingga kurang mampu dalam mengembangkan KON siswa. Hal ini dapat di lihat dari hasil penelitian yang telah di paparkan sebelumnya bahwa KON siswa yang mendapat model pembelajaran langsung lebih rendah daripada siswa yang 
mendapat PKTJK .Dalam proses pembelajaran dengan menggunakan model pembelajaran langsung terhadap KON siswa tidaklah mudah dilakukan. Oleh karena itu, dibutuhkan suatu PKTJK yang memudahkan siswa mengembangkan keterampilan berpikirnya dalam menghubungkan masalah kehidupan sehari-hari.

PKTJK diawali dengan guru mengarahkan siswa pada situasi atau masalah yang nyata pada keseharian siswa, misalnya bagaimana siswa menghubungkan konsep matematika dengan konsep matematika lainnya ataupun dengan bidang ilmu lain serta menghubungkan dengan kehidupan sehari-hari. Hal ini dapat membangkitkan rasa ingin tahu siswa sehingga mereka tertarik untuk menyelidiki dan sekaligus mengaplikasikannya dalam kehidupan sehari-harinya ketika pulang dari sekolah.

Jika dilihat dari karakteristik PKTJK, sebagaimana telah dijelaskan sebelumnya kondisi ini dimungkinkan terjadi. Siswa yang mendapat PKTJK

\section{KESIMPULAN DAN SARAN}

Kesimpulan dari penelitian ini yaitu: (1) Kemampuan KON siswa kelas X SMA Negeri 1 Wakorumba Utara meningkat setelah di berikan atau menggunakan masalah kontekstual. (2) Disposisi Matematik siswa pada kelas X SMA Negeri 1 Wakorumba Utara terdiri dari tiga kategori yaitu disposisi matematik tinggi, sedang dan rendah. (3) Proses pembelajaran kooperatif tipe jigsaw kontekstual dan pembelajaran langsung kontekstual pada siswa kelas X SMA Negeri 1 Wakorumba Utara terlaksana dengan baik. Siswa terlibat dalam menyelesaikan masalah yang diberikan. (4) peningkatan kemampuan koneksi matematik siswa Kelas X-3 SMA Negeri 1 Wakorumba Utara yang diajar dengan pembelajaran kooperatif tipe jigsaw kontekstual pada materi perbandingan trigonometri tergolong pada klasifikasi belajar secara kooperatif melalui proses pemberian masalah kontekstual seharisehari siswa atau masalah kontekstual yang disimulasikan. Pada proses pengajuan masalah tersebut, siswa menggunakan segala potensi yang dimilikinya untuk menyelesaikan masalah yang diberikan baik secara mandiri maupun secara kooperatif untuk diajukan pada diskusi kelas. Ketika siswa mendapat masalah, mereka mengemukakan pertanyaan kepada guru atau kepada siswa lain untuk memperjelas masalah dan berbagai tugas yang diberikan. Pada saat yang sama, siswa dapat saling berbagi, mempertahankan, atau menghargai pendapat yang dikemukakan oleh siswa lain. Kegiatan ini dapat menumbuhkembangkan pemahaman siswa terhadap masalah matematika yang diberikan sehingga dapat mempermudah mereka untuk mengembangkan keterampilan berpikirnya, ditunjukkan oleh meningkatnya kemampuan koneksi matematik siswa.

sedang. (5) Peningkatan kemampuan koneksi matematik siswa Kelas X-1 SMA Negeri 1 wakorumba Utara yang diajar dengan PLK pada materi perbandingan trigonometri tergolong pada klasifikasi sedang. Artinya secara keseluruhan kemampuan koneksi matematik siswa tergolong sedang. (6) Secara signifikan peningkatan KON siswa yang diajar dengan PKTJK lebih tinggi daripada siswa yang diajar PLK. (7) Secara signifikan peningkatan kemampuan KON matematik siswa antara yang diajar dengan PKTJK lebih tinggi daripada peningkatan kemampuan KON matematik siswa yang diajar dengan PLK ditinjau dari DM. (8) Secara signifikan KON siswa yang diajar dengan PKTJK lebih tinggi daripada KON siswa yang diajar dengan PLK ditinjau dari siswa yang memiliki DM tinggi. (9) Secara signifikan tidak ada perbedaan 
kemampuan KON siswa yang diajar dengan PKTJK dan kemampuan KON siswa yang diajar dengan PLK ditinjau dari siswa yang memiliki DM sedang. (10) Secara signifikan tidak ada perbedaan kemampuan KON antara siswa yang diajar dengan PKTJK dan kemapuan KON siswa yang diajar dengan PLK ditinjau dari siswa yang memiliki DM rendah.

Saran dalam penelitian ini yaitu: (1) Pembelajaran Kooperatif tipe Jigsaw Kontekstual baik untuk meningkatkan kemampuan koneksi matematik siswa. (2) KON siswa perlu dikembangkan lagi untuk membantu siswa mengembangkan kemampuan berpikirnya, baik dalam

\section{DAFTAR PUSTAKA}

Anghileri, J. 2006. Scaffolding Practices that Enhance Mathematics Learning. Journal of Mathematics Teacher Education. SpringerVerlag Berlin Heidelberg

Aronson, Elliot. 2008. Jigsaw Classroom. [Online].

Tersedia: http://www.jigsaw.net. [2 Oktober 2016].

Depdiknas. 2002. Pendekatan Kontekstual (Contextual Teaching and Learning (CTL)). Jakarta: Direktorat Pendidikan Lanjutan Pertama, Direktorat Jenderal Pendidikan Dasar Menengah

Jihad, A. 2008. Pengembangan Kurikulum Matematika (Tinjauan Teoritis dan Historis). Bandung: Multipressindo.

NCTM, 2000. Principles and Standards for School Mathematics. Reston, VA: NCTM.

Soedjadi. 2000. Kiat Pendidikan Matematika di Indonesia. [Online]. http://muttaqinhasyim.wordpress.c om/2009/06/14/tujuan-

pembelajaran-matematika/. pembelajaran matematika maupun dalam kehidupan sehari-hari siswa. Salah satu alternatif pembelajaran yang dapat digunakan adalah PKTJK. (3) Guru perlu memberikan siswa soal-soal yang berhubungan dengan aspek-aspek KON dalam pembelajaran di kelas agar kemampuan siswa terlatih dalam mengembangkan kemampuan koneksi matematik. (4) Guru perlu mengembangkan lembar kerja siswa (LKS) yang dapat diaplikasikan dan/atau digunakan pada materi matematika yang lain dengan menerapkan PKTJK.

Sukardi. 2003. Metodologi Penelitian Pendidikan . Yogyakarta: Bumi Aksara.

Walpole, R.E. 1993. Pengantar Statistika. Jakarta: PT Gramedia Pustaka Urama.

Januari 2016]. 